\title{
Neutrophil count to albumin ratio as a new predictor of mortality in patients with COVID-19 Infection
}

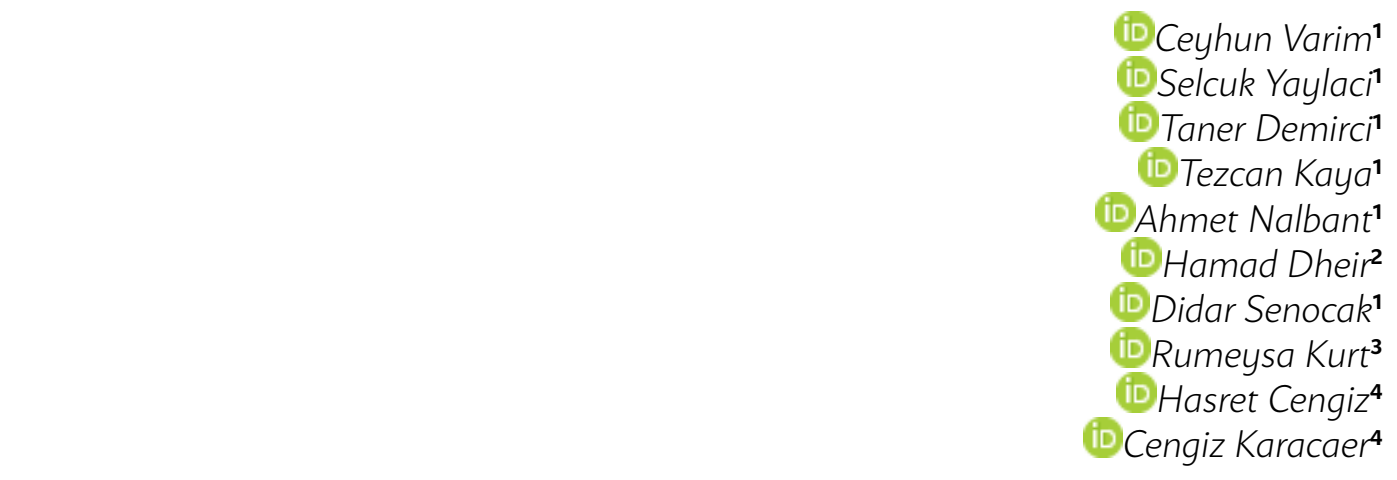

1. Associate Professor, Department of Internal Medicine, Sakarya University Medicine Faculty, Sakarya, Turkey. 2. Associate Professor, Department of Internal Medicine Division of Nephrology, Sakarya University Medicine Faculty, Sakarya, Turkey. 3. Medical Doctor, Department of Internal Medicine, Sakarya University Medicine Faculty, Sakarya, Turkey. 4. Hasret Cengiz, Medical Doctor, Department of Endocrinology, Sakarya University Medicine Faculty, Sakarya, Turkey.

\section{SUMMARY}

BACKGROUND: Coronavirus Disease 2019 is an acute inflammatory respiratory disease. It causes many changes in hemogram parameters. Low albumin levels are associated with mortality risk in hospitalized patients. The aim of the present study is to reveal the place of neutrophil count to albumin ratio in predicting mortality in patients with COVID-19.

METHODS: 144 patients, 65 females and 79 males, were included in the study. Patients were divided into 2 groups. Group 1 was the non-severe group (n:85), and Group 2 was severe (n:59). Demographic data, neutrophil, lymphocyte and platelet counts, albumin and $C$-reactive protein (CRP) levels were recorded. Neutrophil count to albumin ratio (NAR) was calculated by dividing the absolute neutrophil counts by the albumin levels. The NAR and levels of the two groups were then compared.

RESULTS: There were no significant differences in gender and platelet count (201 vs. $211 \mathrm{~K} / \mathrm{mL}$ ) between the groups ( $p>0,05)$. Ages (62.0 \pm 14.3 vs $68.6 \pm 12.2$ years), albumin (33.1 vs $29.9 \mathrm{gr} / \mathrm{L}), C R P(33 \mathrm{vs} 113 \mathrm{mg} / \mathrm{l})$, neutrophil count (4 vs $7.24 \mathrm{~K} / \mathrm{mL}$ ), WBC counts (6.70 vs $8.50 \mathrm{~K} / \mathrm{mL}$ ), NAR values (113.5 vs 267.2) and number of Death (5 vs 33) were found to be statistically higher ( $p<0.001$ ) in Group 2 than in Group 1. The NAR value of 201.5 showed mortality in all patients with COVID-19 to have $71.1 \%$ sensitivity and $71.7 \%$ specificity (AUC:0.736, 95\% Cl: 0.641-0.832, $p<0.001$ )

CONCLUSION: The present study showed that NAR levels can be a cheap and simple marker for predicting mortality in patients with COVID-19.

KEYWORDS: Neutrophils. Albumins. Coronavirus Infections. Mortality.

DATE OF SUBMISSION: 05-JUL-2020

DATE OF ACCEPTANCE: $11-J \mathrm{Ul}-2020$

CORRESPONDING AUTHOR: Ceyhun Varım

Adnan Menderes caddesi, Sağlık Sokak, n.195, Adapazarı, Sakarya, Turkey - 54000

Tel: +90 264 255-2106 / Fax: +90 264 255-2105

E-mail: ceyhunvarim@sakaryaedu.tr 


\section{INTRODUCTION}

The Coronavirus Disease 2019 (COVID-19), as named by the World Health Organization, was caused by the severe acute respiratory syndrome coronavirus (SARS-CoV)-2. This novel virus is a member of the coronavirus family, like SARS-CoV and Middle East respiratory syndrome coronavirus. Coronaviruses (CoVs) are single chain, enveloped RNA viruses with positive polarity. Coronaviruses are animal-derived viruses (zoonotic). They can cause infection in humans and various animals, including mammals, birds, camels, cats, and bats. As a result of detailed research, it has been revealed that SARS-CoV is transmitted from musk cats and MERS-CoV is transmitted from single-humped camels to humans. The source of the SARS-CoV-2 infection has not become clear yet. The options available indicate that wild animals used illegally in the Huanan Chinese Seafood Wholesale Market could have been responsible for it $^{1-4}$.

Neutrophils drive the early inflammatory response following an acute infection, and high neutrophil count was demonstrated as an important marker for systemic infection ${ }^{5}$. Albumin is a negative acute-phase reactant and decreases in acute infection. Low albumin levels are associated with mortality risk in hospitalized patients ${ }^{6}$. Neutrophil/albumin ratio (NAR) is a new marker indicating systemic inflammation and mortality which can be calculated using hemogram parameters. This is a cheap and easy method to predict mortality in patients with COVID-19.

In this study, we aim to reveal the place of neutrophil count to albumin ratio in predicting mortality in patients with COVID-19.

\section{Methods}

A total of 144 patients (65 women, 79 men) who had been hospitalized at the clinic of internal medicine of the Sakarya University Medicine Faculty between 01 April 2020 and 31 May 2020 and tested for COVID-19 with real-time reverse transcription-polymerase chain reaction (RRT-PCR) were enrolled in the study. Nasal and pharyngeal swabs of all patients were obtained. The isolated patient samples that were obtained with VNAT viral transport and brought to the molecular virology laboratory were examined using the Biospedy (Bioeksen, Turkey) RRT-PCR kit provided by the Ministry of Health of Turkey. The patients whose RRT-PCR results were positive were regarded as COVID-19 (+). Hospital records (demographic, clinical, and laboratory data) of the cases above 18 years old were analyzed retrospectively. The patients were divided into two groups based on the severity of the disease. Thus, there was a non-critical group (consisting of 85 patients) and a critical group (consisting of 59 patients). critical illnesses include patients with respiratory failure, shock, or multiorgan dysfunction. The white blood cell (WBC) count, neutrophil, lymphocyte count, platelet, and albumin values of all patients were recorded, and the NAR (neutrophil count/albumin) values were calculated.

Hemogram results and biochemical results at the time of diagnosis were measured. Hematological parameters were analyzed using a hematology analyzer (Abbott CELL DYN 3700 System, Ramsey, Minnesota 55303, USA) within 30 minutes. The reports from the thoracic computed tomographies were obtained from a data management system. Serum urea, creatinine, aspartate aminotransferase (AST), alanine aminotransferase (ALT), and albumin were analyzed using the kinetic alkaline picrate method with the Architect C 16000 (Abbott) device at the biochemistry laboratory of the hospital.

This study was approved by the local ethics committee and performed in accordance with the Helsinki Declaration (18.04.2019-71522473/050.01.04/55).

\section{Statistical Analysis}

Data analysis was performed by using SPSS-22 for Windows (Statistical Package for Social Science, SPSS Inc. Chicago IL, USA ${ }^{\circledR} \mathrm{Z}$ ). The variables were investigated using visual (histograms, probability plot) and analytical methods (Kolmogorov-Smirnov/ Shapiro-Wilk's test) to determine whether or not they are normally distributed. We performed analyses to describe and summarize the distributions of variables. The continuous variables were expressed as mean and standard deviation or as median and interquartile range, depending on the normality of their distribution. Categorical variables were interpreted by frequency tables. The Mann-Whitney U test was used to compare the variables that were not normally distributed. On the other hand, the Student's t-test was used to compare the variables with a normal distribution. Categorical features and relationships between groups were assessed using an appropriate chi-square test. Logistic regression was conducted to assess whether the predictor variables such as laboratory rates significantly predict mortality. The capacities of the neutrophil percentage to albumin ratio and neutrophil count to albumin ratio parameters to predict mortality 
were analyzed by the "Receiver Operating Properties (ROC)" curve analysis. In the presence of significant limit values, the sensitivity and specificity values of these limits were calculated. While evaluating the area under the curve, a 5\% type-1 error level was used to accept a statistically significant predictive value of the test variables. The statistically significant two-tailed p-value was considered as $<0.05$.

\section{RESULTS}

A total of 144 patients were included in this retrospective study. The groups (Group 1 of non-critical patients, Group 2 of critical patients) were determined to be homogenous in terms of gender. There were no significant gender differences between the two groups. The average age was $62.0 \pm 14.3$ years in Group 1 and $68.6 \pm 12.2$ years in Group 2 at $\mathrm{p}<0.004$. (Table 1 ).

The white Blood Cell (WBC), platelet, neutrophil counts, albumin, D-dimer, ferritin, and C-reactive protein (CRP), and NAR levels of Group 1 and Group 2 are shown in Table 2.

TABLE 1. DEMOGRAPHIC CHARACTERISTICS

\begin{tabular}{l|l|l|l} 
Parameters & $\begin{array}{l}\text { Non-critical } \\
\text { patients }\end{array}$ & Critical patients & P-values \\
\hline Patients $(n)$ & 85 & 59 & \\
\hline Male/Female $(n)$ & $48 / 37$ & $19 / 208$ & 0.641 \\
\hline Age (years) & $62.0 \pm 14.3$ & $68.6 \pm 12.2$ & 0.004 \\
\hline
\end{tabular}

TABLE 2. COMPARISON OF CLINICAL AND LABORATORY RESULTS

\begin{tabular}{l|l|l|l} 
Parameters & $\begin{array}{l}\text { Non-critical } \\
\text { patients }(\mathrm{n}: 85)\end{array}$ & $\begin{array}{l}\text { Critical } \\
\text { Patients (n:59) }\end{array}$ & P-values \\
\hline D-Dimer (ng/mL) & $\begin{array}{l}657.0 \\
(319-1470)\end{array}$ & $\begin{array}{l}1680 \\
(844-3690)\end{array}$ & $<0.001$ \\
\hline Ferritin $(\mathrm{ng} / \mathrm{mL})$ & $\begin{array}{l}348.0 \\
(165.5-637.5)\end{array}$ & $\begin{array}{l}776.0 \\
(411.0-1545.0)\end{array}$ & $<0.001$ \\
\hline CRP $(\mathrm{mg} / \mathrm{L})$ & $\begin{array}{l}33.0 \\
(10.95-72.20)\end{array}$ & $\begin{array}{l}113.0 \\
(37.2-169.0)\end{array}$ & $<0.001$ \\
\hline WBC $(\mathrm{K} / \mathrm{mL})$ & $\begin{array}{l}6.70 \\
(4.75-8.00)\end{array}$ & $\begin{array}{l}8.50 \\
(5.80-14.90)\end{array}$ & $<0.001$ \\
\hline PLT $(\mathrm{K} / \mathrm{mL})$ & 201 & $\begin{array}{l}211 \\
(149-277)\end{array}$ & 0.858 \\
& $(163.5-270.5)$ & $\begin{array}{l}7.24 \\
(3.90-12.40)\end{array}$ & $<0.001$ \\
\hline NEU $(\mathrm{K} / \mathrm{mL})$ & $\begin{array}{l}4.00 \\
(3.00-5.77)\end{array}$ & $\begin{array}{l}29.90 \\
(26.60-33.00)\end{array}$ & $<0.001$ \\
\hline Albumin (gr/L) & $\begin{array}{l}33.10 \\
(29.85-37.05)\end{array}$ & $\begin{array}{l}267.2 \\
(128.9-409.2)\end{array}$ & $<0.001$ \\
\hline NAR & 113.5 & $33(55)$ & $<0.001$ \\
\hline Death $\mathrm{n}(\%)$ & $5(5.9)$ & $201.8)$ & \\
\hline
\end{tabular}

NAR: Neutrophil Count to Albumin Ratio; WBC: White Blood Cell; CRP: C-reactive protein.
WBC counts were $6.7010^{3} / \mathrm{mm}^{3}(4.75-8.00)$ in Group 1 and $8.5010^{3} / \mathrm{mm}^{3}(5.80-14.90)$ in Group 2 at $p<0.001$. The platelet counts were $201 \mathrm{~K} / \mathrm{mL}(163.5$ - 270.5) in Group 1 and $211 \mathrm{~K} / \mathrm{mL}$ (149-277) in Group 2 , at $\mathrm{p}=0.858$. The neutrophil counts were $4.0 \mathrm{~K} / \mathrm{mL}$ (3.00 - 5.77) in Group 1 and $7.24 \mathrm{~K} / \mathrm{mL}(3.90$ - 12.40) in Group 2, at $\mathrm{p}<0.001$. Albumin levels were $33.10 \mathrm{gr} / \mathrm{L}$ (29.85 - 37.05) in Group 1 and 29.90 (26.60 - 33.00) in Group 2, at $\mathrm{p}<0.001$, and the D-dimer levels were $657.0 \mathrm{ng} / \mathrm{mL}$ (319 - 1470) in Group 1 and $1680 \mathrm{ng} / \mathrm{mL}$ (844 - 3690) in Group 2, at $\mathrm{p}<0.001$. The ferritin levels were $348.0 \mathrm{ng} / \mathrm{mL}(165.5$ - 637.5) in Group 1 and 776.0 $\mathrm{ng} / \mathrm{mL}(411.0$ - 1545.0) in Group 2, at $\mathrm{p}<0.001$. The CRP levels were $33.0 \mathrm{mg} / \mathrm{L}(10.95-72.20)$ in Group 1 and $113.0 \mathrm{mg} / \mathrm{L}(37.2-169.0)$ in Group 2, at $\mathrm{p}<0.001$. The mean NAR values were 113.5 (81.5 - 201.8) in Group 1 and $267.2(128.9-409.2)$ in Group 2 at $p<0.001$. The number of deaths was 5 in Group 1 and 33 in Group 2 , at $\mathrm{p}<0.001$ (re-1) (Table 2).

The ROC analysis was performed to determine the cut off values of NAR to predict mortality in patients with a COVID-19 infection. The ROC curve is shown in Figure 1. NAR was predictive at 201.5, with 71.1\% sensitivity and $71.7 \%$ specificity (AUC:0.736, 95\% CI: 0.641-0.832, $\mathrm{p}<0.001$ ) (Figure 2).

\section{DISCUSSION}

We found higher WBC, neutrophil, D-dimer, CRP, ferritin, and NAR values and lower lymphocyte and albumin values in the critical patients than in the non-critical patients in our study. Higher WBC,

FIGURE 1. THE RESULTS OF "NEUTROPHIL COUNT TO ALBUMIN RATIO" WERE SCHEMATIZED ACCORDING TO WHETHER THE DISEASE WAS CRITICAL OR NOT.

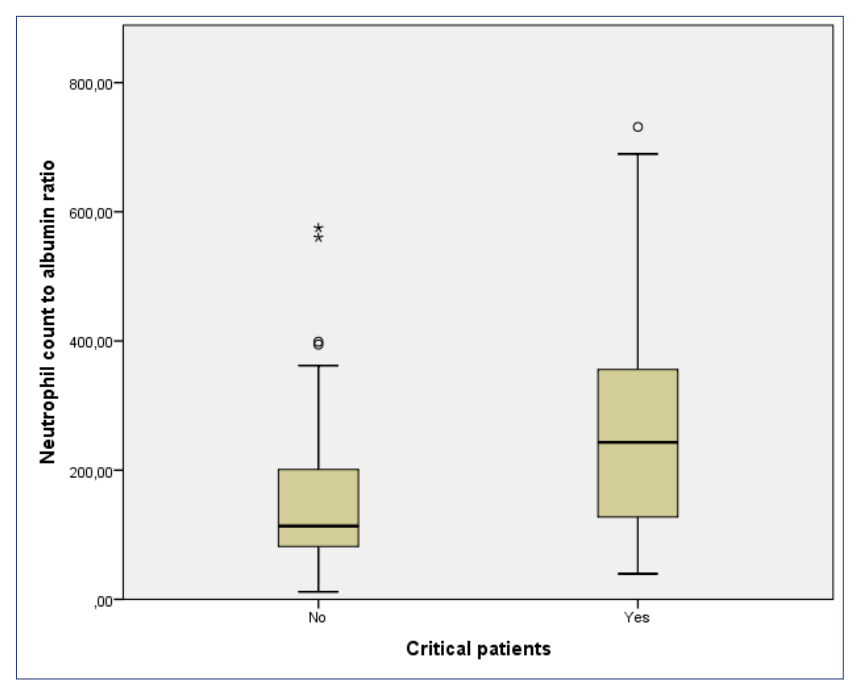


FIGURE 2. RECEIVER OPERATING CHARACTERISTIC (ROC) CURVE OF NEUTROPHIL COUNT TO ALBUMIN RATIO IN PREDICTING MORTALITY.

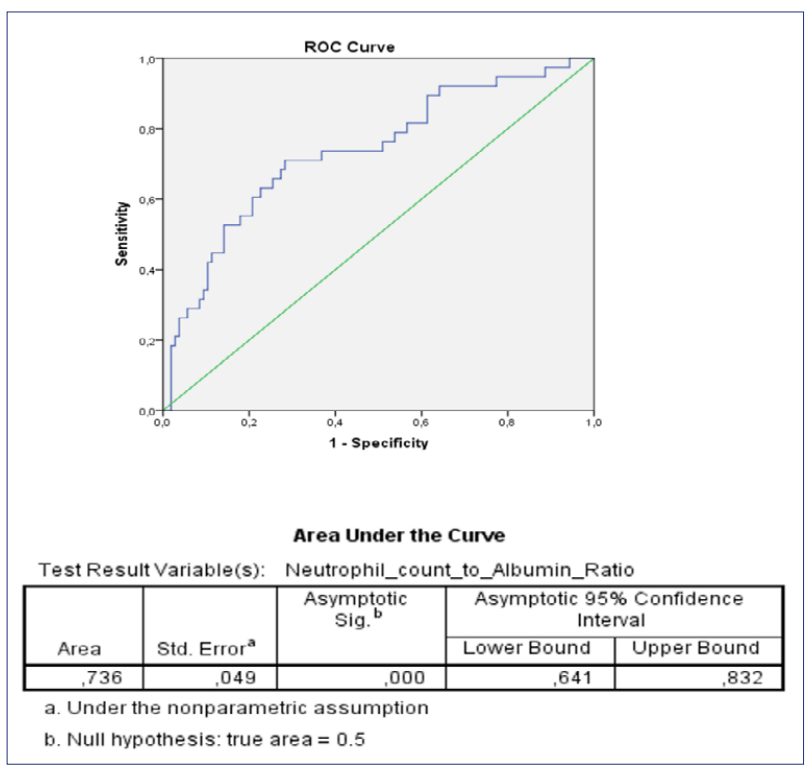

neutrophil, D-dimer, CRP, ferritin, and NAR values and lower lymphocyte and albumin values are associated with poor prognosis.

We performed a ROC analysis for NAR values, and basal NAR greater than 201.5 had $71.1 \%$ sensitivity and $71.7 \%$ specificity in predicting the mortality of patients with a COVID-19 infection.

Neutrophils and lymphocytes are important components of the immune system. Neutrophils are cells that release chemokines and cytokines. These released cytokines and chemokines stimulate angiogenesis, cytogenesis, antiviral defense, and help regulate the immune response ${ }^{7}$. In severe viral infections, the number of neutrophils in the peripheral blood increases significantly; increased neutrophil counts induce a cytokine-chemokine storm and, ultimately, lead to lung injury and acute respiratory distress syndrome ${ }^{8}$.

When the literature is examined, there are many studies on neutrophil count and neutrophil/lymphocyte ratio (NLR) in COVID-19 patients. The relationship between neutrophil counts, NLR, and mortality has been examined in COVID-19 patients in some of these studies, as has the prognosis of COVID-19 in other studies $^{8-11}$. We found a positive relationship between neutrophil counts and poor prognosis and mortality. Our findings are consistent with the literature.

Albumin is the biggest and most abundant protein in plasma. Albumin is found in high concentrations in the intestine, muscle, skin, and all body fluids. Albumin interacts with many endogenous and exogenous molecules. There is a complex relationship between intracellular and extracellular albumin levels. Intracellular albumin intake increases and serum albumin levels decrease due to stress and inflammation. Albumin is also known as a negative acute phase reactant with low blood levels in acute inflammation and inversely associated with the magnitude of systemic inflammatory response. Low albumin levels are associated with mortality risk in hospitalized patients $\mathbf{6}^{6,2-14}$.

We found low albumin levels in our study. Low albumin levels are associated with poor prognosis and mortality. Our findings are consistent with the literature. Aziz et al. ${ }^{15}$ made a meta-analysis of 11 studies that examined serum albumin levels in patients with COVID-19. In ten of these eleven studies, an inverse proportion was found between low serum albumin levels and the severity of the disease. In one, this relationship was not observed. In another study, serum albumin levels were found to be significantly lower in patients with COVID-19 than in healthy individuals ${ }^{16}$. In a study by Mishra et al. ${ }^{17}$, serum albumin-mediated strategies were shown to be useful in the treatment of patients with COVID-19.

We developed and tested a simple index of the neutrophil count to albumin ratio (NAR) for predicting mortality of COVID-19 and found $71.1 \%$ sensitivity and $71.7 \%$ specificity. This simple index can be used instead of the neutrophil/lymphocyte ratio, platelet/ lymphocyte ratio, fibrinogen/albumin ratio, and lymphocyte/C-reactive protein ratio.

High admission NAR was identified as an independent predictor in patients with COVID-19. Our results suggest that COVID-19 patients with high NAR values should be carefully monitored and considered for intensive care because of the close association with early mortality. Further studies are still required to confirm and illuminate the clinical implications of these findings.

\section{Conflict of Interest}

All authors declare that there is no potential conflict of interest relevant to this article.

\section{Author's Contribution}

Concept: Ceyhun Varım; Design: Selçuk Yaylacı; Literature search: Cengiz Karacaer; Clinical studies: Ahmet Nalbant; Data acquisition: Hamad Dheir; Data analysis: Hasret Cengiz; Statistical analysis: Taner Demirci; Manuscript preparation: Tezcan Kaya; Manuscript editing: Didar Senocak; Manuscript review: Rumeysa Kurt. 


\section{RESUMO}

ANTECEDENTES: A doença de coronavírus 2019 é uma doença respiratória inflamatória aguda. Causa muitas alterações nos parâmetros do hemograma. Baixos níveis de albumina estão associados ao risco de mortalidade em pacientes hospitalizados. O objetivo do presente estudo é revelar o local da razão entre contagem de neutrófilos e albumina na predição de mortalidade em pacientes com COVID-19.

MÉTODOS: Cento e quarenta e quatro pacientes do sexo feminino e 79 do sexo masculino foram incluídos no estudo. Os pacientes foram divididos em dois grupos: Grupo 1 não grave (n: 85), Grupo 2 grave (n: 59). Dados demográficos, contagem de neutrófilos, linfócitos e plaquetas, níveis de albumina e proteína $C$ reativa $(P C R)$ foram registrados. A razão de contagem de neutrófilos para albumina (NAR) foi calculada dividindo-se as contagens absolutas de neutrófilos pelos níveis de albumina. O NAR e os níveis dos dois grupos foram comparados.

RESULTADOS: Não houve diferenças significativas no sexo e na contagem de plaquetas (201 vs $211 \mathrm{~K} / \mathrm{mL}$ ) entre os grupos ( $p>0,05)$ ). Idade (62,0 $\pm 14,3$ vs 68,6 $\pm 12,2$ anos), albumina (33,1 vs 29,9 gr/L), PCR (33 vs $113 \mathrm{mg} / \mathrm{l})$, contagem de neutrófilos (4 vs 7,24 K/mL), contagem de leucócitos (6,70 vs $8,50 \mathrm{~K} / \mathrm{mL}$ ), valores de NAR (113,5 vs 267,2) e número de óbitos (5 vs 33) foram estatisticamente maiores ( $p<0,001$ ) no Grupo 2 que no Grupo 1. O valor NAR de 201,5 mostrou mortalidade em todos os pacientes com COVID-19 com sensibilidade de 71,1\% e especificidade de 71,7\% (AUC: 0,736, IC 95\%: 0,641-0,832, p<0,001).

CONCLUSÃO: O presente estudo mostrou que os níveis de NAR podem ser um marcador barato e simples para predizer mortalidade em pacientes com COVID-19.

PALAVRAS-CHAVE: Neutrófilos. Albuminas. Infecções por coronavírus. Mortalidade.

\section{REFERENCES}

1. Gorbalenya AE, Baker SC, Baric RS, de Groot RJ, Drosten C, Gulyaeva AA et al. Severe acute respiratory syndrome-related coronavirus: the species and its viruses - a statement of the Coronavirus Study Group. bioRxiv. 2020. doi: https://doi.org/10.1101/2020.02.07.937862.

2. Chen Y, Liu Q, Guo D. Emerging coronaviruses: genome structure, replication, and pathogenesis. J Med Virol. 2020;92(4):418-23.

3. Hui DS. Epidemic and emerging coronaviruses (severe acute respiratory syndrome and middle east respiratory syndrome). Clin Chest Med. 2017;38(1):71-86

4. $\mathrm{Wu} J \mathrm{~T}$, Leung $\mathrm{K}$, Leung GM. Nowcasting and forecasting the potential domestic and international spread of the 2019-nCoV outbreak originating in Wuhan, China: a modelling study. Lancet. 2020;395(10225):689-97.

5. Liu Y, Du X, Chen J, Jin Y, Peng L, Wang HHX, et al. Neutrophil-to-lymphocyte ratio as an independent risk factor for mortality in hospitalized patients with COVID-19. J Infect. 2020;81(1):e6-e12.

6. Akirov A, Masri-Iraqi H, Atamna A, Shimon I. Low albumin levels are associated with mortality risk in hospitalized patients. Am J Med. 2017;130(12):1465. e11-1465.e19.

7. Tecchio C, Micheletti A, Cassatella MA, Neutrophil-derived cytokines: facts beyond expression. Front Immunol. 2014;5:508.

8. Wang $H$, Zhang Y, Mo P, Liu J, Wang H, Wang F, et al. Neutrophil to CD4+ lymphocyte ratio as a potential biomarker in predicting virus negative conversion time in COVID-19. Int Immunopharmacol. 2020;85:106683.

9. Wan S, Xiang Y, Fang W, Zheng Y, Li B, Hu Y, et al. Clinical features and treatment of COVID-19 patients in northeast Chongqing. J Med Virol. 2020;92(7):797-806.
10. Huang C, Wang Y, Li X, Ren L, Zhao J, Hu Y, et al. Clinical features of patients infected with 2019 novel coronavirus in Wuhan, China. Lancet. 2020;395(10223):497-506.

11. Yan X, Li F, Wang X, Yan J, Zhu F, Tang S, et al. Neutrophil to lymphocyte ratio as prognostic and predictive factor in patients with coronavirus disease 2019: a retrospective cross-sectional study. J Med Virol. 2020;10.1002/ jmv.26061.

12. Mishra PM, Uversky VN, Nandi CK. Serum albumin-mediated strategy for the effective targeting of SARS-CoV-2. Med Hypotheses. 2020;140:109790.

13. Chojkier M. Inhibition of albumin synthesis in chronic diseases: molecular mechanisms. J Clin Gastroenterol. 2005;39(4 Suppl 2):S143-6.

14. Koh YW, Lee HW. Prognostic impact of C-reactive protein/albumin ratio on the overall survival of patients with advanced nonsmall cell lung cancers receiving palliative chemotherapy. Medicine (Baltimore). 2017;96(19):e6848.

15. Aziz M, Fatima R, Lee-Smith W, Assaly R. The association of low serum albumin level with severe COVID-19: a systematic review and meta-analysis. Crit Care. 2020;24(1):255.

16. Mardani R, Vasmehjani AA, Zali F, Gholami A, Mousavi Nasab SD, Kaghazian $\mathrm{H}$, et al. Laboratory parameters in detection of COVID-19 patients with positive RT-PCR: a diagnostic accuracy study. Arch Acad Emerg Med. 2020;8(1):e43.

17. Mishra PM, Uversky VN, Nandi CK. Serum albumin-mediated strategy for the effective targeting of SARS-CoV-2. Med Hypotheses. 2020;140:109790. 